\title{
Low-Temperature Cytochrome Spectra of Anaerobic Actinomycetes
}

\author{
SVETLANA D. TAPTYKOVA AND L. V. KALAKOUTSKII \\ Institute of Microbiology, U.S.S.R. Academy of Sciences, Moscow, Union of Soviet Socialist Republics
}

\begin{abstract}
A sensitive, low-temperature spectrophotometric technique was used to detect the presence and relative contents of cytochromes resembling hemoproteins in suspensions of intact cells of 15 strains of anaerobic actinomycetes. The cytochrome content of most cultures was increased by aerated cultivation. Anaerobically grown cells of Actinomyces israelii serotype 2 contained virtually no cytochromes whereas those of $A$. israelii serotype 1, Actinomyces viscosus, and Actinomyces bovis, in this order, show an increased concentration of only cytochrome $b$ (hemoprotein 559). Under aerobic conditions, $A$. viscosus was able to synthesize cytochromes $c$ and $a$. No correlation was found between spectrophotometric and benzidine test data. Cytochrome spectra may be useful in differentiating serotype 1 from serotype 2 of $A$. israelii and differentiating $A$. bovis from the other species of Actinomyces studied.
\end{abstract}

Despite the fact that the presence of cytochromes in anaerobic actinomycetes was first mentioned over 30 years ago (13), relatively little attention has been paid to the cytochromes in extensive studies on the physiology and biochemistry of these organisms (for a review of the latter, see reference 12). Our preliminary observations (15) suggested that application of a recently developed sensitive technique (9) for the study of cytochromes in these organisms might be instrumental in providing further information on the differences between aerobic and anaerobic members of the order Actinomycetales as well as on the utility of cytochrome spectra for identification purposes. This paper summarizes the results of experiments performed on 15 strains of anaerobic actinomycetes differing in their ability to grow at different levels of aeration.

\section{MATERIALS AND METHODS}

Bacterial strains. The list of strains used in this study is given in Table 1 .

Methods. Cultures were grown in a liquid medium composed of a standard meat-peptone broth (MPB) supplemented with glucose $(0.05 \% \mathrm{wt} / \mathrm{vol})$ and, when indicated, with sodium thioglycollate $(0.05 \% \mathrm{wt} / \mathrm{vol})$, cysteine $(0.1 \% \mathrm{wt} / \mathrm{vol})$, or sodium ascorbate $(0.1 \%$ $\mathrm{wt} / \mathrm{vol}$ ), as reducing agent. The autoclaved medium was dispensed into sterile flasks with cotton plugs, heated in a boiling water bath for $30 \mathrm{~min}$ to remove dissolved oxygen, and then poured into sterile $600-\mathrm{ml}$ flasks (up to their necks), rapidly cooled, and inoculated. The flasks were then stoppered with sterile rubber stoppers and incubated at $35 \mathrm{C}$ for 7 to 10 days. In some of the experiments, organisms were grown under aerobic conditions either as stationary or as shaken cultures. Growth was stopped by cooling the cultures to $4 \mathrm{C}$, and cells were killed by adding Formalin to a final concentration of $0.5 \%(\mathrm{vol} / \mathrm{vol})$. Cells were harvested by centrifugation and washed three times using cooled $1 / 15 \mathrm{M}$ phosphate buffer (pH 7.0). The material was kept frozen until used.

Cy tochromes were assayed using a low-temperature spectrophotometric procedure described previously (9). The concentration of hemoproteins was calculated from the absolute spectra in preparations reduced with sodium dithionite and was expressed in terms of optical density units per unit of dry weight of cells. The molar extinction coefficient of mammalian cytochrome $b$ was used for calculation of the hemoprotein (as cytochrome $b$ ) content in micromoles per milligram of dry weight of cells as described elsewhere (3). For dry weight determinations, the samples were dried on membrane filters over anhydrous $\mathrm{CaCl}_{2}$ for $24 \mathrm{~h}$. Protoporphyrin was extracted with acid acetone (4). For qualitative detection of iron-porphyrins, a modified benzidine test (2) was employed.

Each set of experiments was performed at least three times.

\section{RESULTS AND DISCUSSION}

As one may see from the data presented in Table 1, all of the strains examined except those belonging to serotype 1 of Actinomyces israelii were characterized by notable absorp- 
TABLE 1. Relative content of hemoprotein (cytochrome b type) in cell suspensions of anaerobic actinomycetes ${ }^{a}$

\begin{tabular}{|c|c|c|c|c|}
\hline \multirow[t]{2}{*}{ Organisms $^{b}$} & \multicolumn{2}{|c|}{$\begin{array}{l}\alpha \text {-Absorption } \\
\text { maxima in li- } \\
\text { quid nitrogen }\end{array}$} & \multicolumn{2}{|c|}{ Hemoprotein content } \\
\hline & $b_{\alpha_{2}}$ & $b_{\alpha_{1}}$ & $\begin{array}{c}\text { OD units } \\
\left(\Delta \mathrm{D} \times 10^{-4}\right. \\
\mathrm{mg})\end{array}$ & $\underset{\left(10^{-4} / \mathrm{mg}\right)}{\mu \mathrm{mol}}$ \\
\hline Actinomyces bovis ATCC 13683 & 554 & 559 & 11.90 & 0.70 \\
\hline A. viscosus ATCC 15987 & 554 & 559 & 3.40 & 0.20 \\
\hline A. viscosus A ТCC $19246^{c}$ & 554 & 559 & 4.20 & 0.25 \\
\hline $\begin{array}{l}\text { A. israelii serotype } 1 \\
\text { ATCC } 12102 \\
\text { ATCC } 10048 \\
\text { WVU } 231 \\
\text { WVU } 232 \\
\text { WVU } 233 \\
\text { WVU } 300 \\
\text { WVU } 306 \\
\text { WVU } 396\end{array}$ & $\begin{array}{l}554^{d} \\
554^{d} \\
554^{d} \\
554^{d} \\
554^{d} \\
554^{d} \\
554^{d} \\
554^{d}\end{array}$ & $\begin{array}{l}559 \\
559 \\
559 \\
559 \\
559 \\
559 \\
559 \\
559\end{array}$ & $\begin{array}{l}1.87 \\
1.36 \\
1.23 \\
1.05 \\
1.18 \\
1.35 \\
1.24 \\
1.36\end{array}$ & $\begin{array}{l}0.11 \\
0.08 \\
0.07 \\
0.06 \\
0.07 \\
0.08 \\
0.07 \\
0.08\end{array}$ \\
\hline $\begin{array}{l}\text { A. israelii serotype } 2 \\
\text { WVU } 301 \\
\text { WVU } 304 \\
\text { WVU } 312 \\
\text { WVU } 326\end{array}$ & $\begin{array}{l}\mathrm{abs}^{e} \\
\mathrm{abs}^{e} \\
\mathrm{abs}^{e} \\
\mathrm{abs}^{e}\end{array}$ & $\begin{array}{l}\operatorname{abs}_{f}^{f} \\
\operatorname{abs}_{f}^{f} \\
\operatorname{abs}_{f}^{f}\end{array}$ & $\begin{array}{l}0-0.3 \\
0-0.2 \\
0-0.1 \\
0-0.2\end{array}$ & $\begin{array}{l}0 \\
0 \\
0 \\
0\end{array}$ \\
\hline
\end{tabular}

${ }^{a}$ Cultures were grown in MPB with glucose and sodium thioglycollate.

${ }^{b}$ Cultures were provided by J. Slack of West Virginia University (WVU). Abbreviations: ATCC, American Type Culture Collection, Rockville, Md.; WVU, West Virginia University, Morgantown, W.Va.

${ }^{c}$ This strain was originally identified as $\boldsymbol{A}$. discofoliatus (5).

$d$ Usually not detected; very slight absorption "shoulder" noted occasionally.

e Absent.

$f$ Practically absent in most cases; slight absorption noted occasionally.

tion maxima in the region of cytochrome $b$. This was especially evident with $A$. bovis. The absorption peak at $559 \mathrm{~nm}$ was asymmetrical, with an additional, smaller maximum at 554 nm (Fig. 1). Both maxima were sharply expressed without adding dithionite when thick suspensions of $A$. bovis and $A$. israelii cells were frozen in liquid nitrogen. This fact suggested that the principal hemoproteins were reduced by intracellular systems and hence may play some physiological role. However, the rate of response to dithionite or intracellular reductants varied with the two peaks. In response to dithionite, the absorption at $559 \mathrm{~nm}$ increased more sharply, possibly signifying the presence of a second absorbing compound.

Analogous but less intensive absorption was evident in dithionite-reduced suspensions of other anaerobic actinomycetes (Table 1), including $A$. viscosus, which is considered to be the most "aerobic" member of the group (14). The spectral patterns were similar in all cases, but maxima were less pronounced with organisms having low hemoprotein content.

When potassium ferricyanide (as oxidizing agent) was added to cell suspensions, the absorption maxima in the cytochrome $b$ region disappeared completely. Extraction of thick cell suspensions with acid acetone also eliminated absorption. The treatment is thought to split noncovalently bound protohemes from the proteins of cytochrome $b$, catalase, and some peroxidases (4). These results provide further evidence for the presence of heme-containing proteins of cytochrome $b$ type.

It should be noted that an asymmetrical absorption peak for cytochrome $b$ has been previously recorded, and it was especially evident with purified cytochrome $b$ from Sclerotinia libertiana (16). 


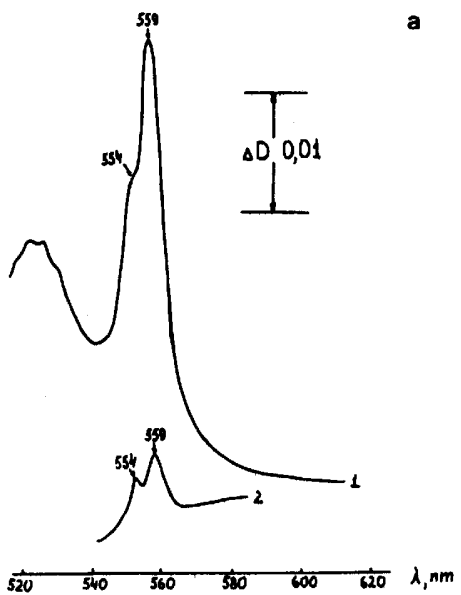

b

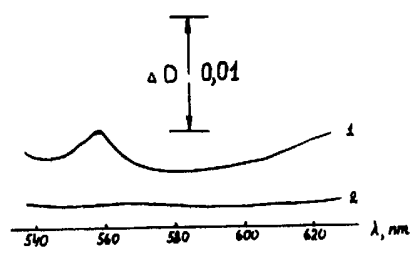

FIG. 1. Low-temperature spectra of cell suspensions of $A$. bovis and A. israelii. a, Thick suspension $(12 \mathrm{mg} d r y$ $w t / \mathrm{ml}$ ) of $A$. bovis ATCC 13683. Dithionite added (1); thick suspension of cells of $A$. bovis ATCC 13683 without dithionite (2). $b, A$. israelii ATCC 10048 (serotype 1), $10 \mathrm{mg}$ dry wt/ml, dithionite added (1); A. israelii WVU 304 (serotype 2), $10 \mathrm{mg}$ dry wt/ml, dithionite added (2).

TABLE 2. Comparison of hemoprotein-559 content in A. israelii cells grown in broth with and without thioglycollate

\begin{tabular}{|c|c|c|c|}
\hline \multirow[b]{2}{*}{ Organisms ${ }^{a}$} & \multirow[b]{2}{*}{ Serotype } & \multicolumn{2}{|c|}{$\begin{array}{l}\text { Hemoprotein content (OD } \\
\text { units }\left[\Delta \mathrm{D} \times 10^{-4}\right] / \mathrm{mg} \text { dry biomass) } \\
\text { in cells grown in media: }\end{array}$} \\
\hline & & + Thioglycollate & - Thiogly collate \\
\hline $\begin{array}{l}\text { Actinomyces israelii } \\
\text { ATCC } 10048 \\
\text { A. israelii WVU } 304\end{array}$ & $\begin{array}{l}1 \\
2\end{array}$ & $\begin{array}{c}1.0-1.3 \\
0\end{array}$ & $\begin{array}{c}2.5-3.4 \\
0-1.45\end{array}$ \\
\hline
\end{tabular}

${ }^{a}$ Abbreviations as in footnote to Table 1.

The hemoprotein (cytochrome $b$ ) content per dry weight unit of cells of $A$. bovis was comparable to that in cells of aerobic actinomycetes when dithionite was employed as a reducing agent. However, in their cytochrome $b$ spectra pattern, the anaerobic cultures differed from the aerobic actinomycetes (15).

The hemoprotein content of cells of $A$. israelii serotype 1 differed significantly from that of cells of serotype 2. The absorption maximum at $559 \mathrm{~nm}$ was practically absent (Fig. 1b) in serotype 2 cells grown in medium supplemented with sodium thioglycollate or other reductant. The same cultures grown in medium without reductants increased their hemoprotein content to equal that of serotype 1 cells grown in medium with reductant (Table 2). It then follows that the hemoprotein content of $A$. israelii cells depends upon the redox condition of cultivation. Cytochrome $b$ was observed in serotype 1 and 2 cells when grown under different conditions.

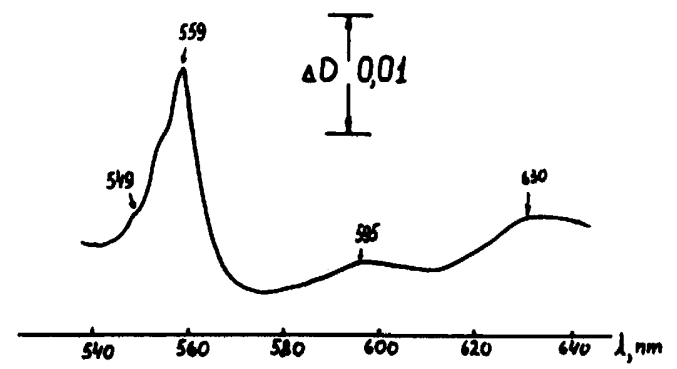

FIG. 2. Low-temperature spectrum of $A$. viscosus cell suspension. Dithionite added. Cells grown under aerobic conditions.

When the more "aerobic" A. viscosus strain ATCC 19246 was grown in stationary or shaken culture with free access of air, the hemoprotein content per biomass unit increased two- to threefold. Absorption at $549 \mathrm{~nm}$ became evident as a small "shoulder." In cell suspensions grown in shaken culture, a notable absorption maximum was seen at $595 \mathrm{~nm}$ and a 
broad peak without a sharply defined maximum was seen at 630 to $640 \mathrm{~nm}$ (Fig. 2). Both maxima disappeared after cell treatment with potassium ferricyanide. There is thus a possibility that under aerobic conditions these cells were able to synthesize other components of the cytochrome chain, notably cytochromes of type $c$ and $a$.

Our attempts to use simple methods for characterizing cytochromes in anaerobic actinomycetes so far have failed. Specifically, we were unable to correlate low-temperature spectrophotometric data with the intensity of color developed with the benzidine test. On the one hand the benzidine test gave negative results, whereas a low-temperature absorption peak in dithionite-reduced suspensions was quite evident. Possible cases of such a discrepancy were discussed earlier (7). On the other hand, there were some cases where the benzidine test gave positive results but low-temperature spectrophotometry failed to reveal noticeable absorption in dithionite-reduced samples. Such data seem to suggest the presence in cells of anaerobic actinomycetes of unidentified porphyrin compounds, since catalase activity is lacking in a majority of these organisms.

According to published spectrophotometric data, cytochromes of types $b, c$, and $a$ are present in aerobic actinomycetes. The $b$ type cytochrome has been partially purified $(1,6)$. However, a detailed comparison of the cytochrome spectra of anaerobic actinomycetes with those reported for aerobes $(10,11)$ is difficult at present because of the lack of information on low-temperature spectra in aerobes generally and on purified cytochrome $b$ in particular. The data presently available indicate that the anaerobic actinomycetes lack cytochrome $a$ and possibly also $c$. In the more aerobic actinomycetes such as $A$. viscosus, cytochromes $a$ and $c$ might be synthesized in response to increased aeration. The total cytochrome $b$ content in the anaerobic actinomycetes grown under restricted aeration (with the exception of $A$. bovis) is much lower than that in the aerobes.

The precise physiological role of the hemoprotein resembling cytochrome $b$ revealed in the present study in cells of most anaerobic actinomycetes is difficult to evaluate. However, the differences in relative content of this component in cells grown under standard conditions might be of value in distinguishing between serotype 1 and serotype 2 of $A$. israelii. Should our data on $A$. bovis be confirmed with other strains of this species, the differentiation of this species from other anaerobic actinomycetes may be facilitated.

\section{ACKNOWLEDGMENT}

We wish to thank J. Slack of West Virginia University for providing the Actinomyces cultures.

\section{LITERATURE CITED}

1. Birk, Y., W. S. Silver, and A. H. Heim. 1957. A $b$ type cytochrome from Streptomyces fradiae. Biochim. Biophys. Acta 25:227-228.

2. Deibel, R. H., and J. B. Evans. 1960. Modified benzidine test for the detection of cytochrome containing respiratory systems in microorganisms. J. Bacteriol. 79:356-360.

3. Evtodienko, Yu. V., and E. N. Mokhova. 1967. Quantitative assay of individual cytochromes in mitochondria, p. 35-48. In Mechanisms of respiration, photosynthesis and nitrogen fixation, Collective vol. Publishing House "Naouka," Moscow.

4. Falk, J. E. 1964. Porphyrins and metalloporphyrins. BBA Library, vol. 2. Elsevier Publishing Co., Amsterdam.

5. Georg, L. K., L. Pine, and M. A. Gerencser. 1969. Actinomyces viscosus, comb. nov., a catalase positive, facultative member of the genus Actinomyces. Int. J. Syst. Bacteriol. 19:291-293.

6. Inoue, Y., and H. Kubo. 1966. The metabolism of Streptomyces griseus. X. A Study of Streptomyces griseus cy tochrome $b$. Biochim. Biophys. Acta 110:57-65.

7. Kalakoutskii, L. V. and Z. Rehaček. 1965. Detection of cytochromes in microbial cells by the benzidine method. Mikrobiologiya 34:366-369.

8. Krasil'nikov, N. A. 1970. Ray fungi (higher forms). Publishing House "Naouka," Moscow.

9. Mokhova, E. N., S. D. Taptykova, and S. G. Sharojan. 1968. Quantitative assay of cytochromes using low-temperature difference spectra. Vop. Med. Khim. 14:437-44I.

10. Niederpruem, D. J., and D. P. Hackett. 1959. Cytochrome system of Streptomycetes. Nature (London) 184:1954-1955.

11. Niederpruem, D. J., and D. P. Hackett. 1961. Respiratory chain of Streptomyces. J. Bacteriol. 84:557-563.

12. Pine, L. 1970. Classification and phylogenetic relationship of microaerophilic actinomycetes. Int. J. Syst. Bacteriol. 20:445-474.

13. Sato, S. 1940. Cytochromes in bacteria, especially Actinomy cetes. Kitasato Arch. Exp. Med. 17:2.

14. Slack, J. M., and M. A. Gerencser. 1970. The genus Actinomyces, p. 19-27. In H. Prauser (ed.), The Actinomycetales. Gustav Fischer Verlag, Jena.

15. Taptykova, S. D., L. V. Kalakoutskii, N. S. Agre, and N. A. Krasil'nikov. 1970. Comparative study on cy tochromes in actinomycetes, p. 305-309. In H. Prauser (ed.), The Actinomycetales. Gustav Fischer Verlag, Jena.

16. Yamanaka, T., T. Horio, and K. Okunuki. 1960. Purification and some properties of a $b$ type cytochrome from Sclerotinia libertiana. Biochim. Biophys. Acta 40:349-351. 